
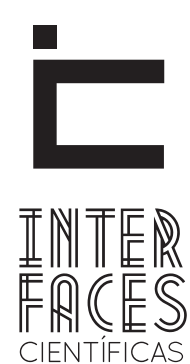

EDUCAÇÃO

ISSN IMPRESSO 2316-333X

E-ISSN 2316-3828

DOI-10.17564/2316-3828.2017v5n2p63-78

\title{
LUZ, CÂMERA, [EDUC]AÇÃO: ENSAIO SOBRE O ATO DE SER PROFESSOR A PARTIR DO FLLME DOGVILLE, DE LARS VON TRIER
}

\section{LIGHT, CAMERA, CEDUCJACTION: TEST ON THE ACT OF BEING A TEACHER FROM THE FLLM DOGVILLE, LARS VON TRIER'S CÁMARA, LUZ, EEDUCJACCIÓN: ENSAYO SOBRE EL ACTO DE SER UN MAESTRO A PARTIR DE LA PELÍCULA DOGVILLE, DE LARS VON TRIER}

Luiz Fernando de Oliveira ${ }^{1}$

\section{RESUMO}

0 presente ensaio tem por objetivo levantar questões consideradas relevantes para a prática docente que se pretenda libertadora, levando-se em conta a condição docente, com todas as suas potencialidades e circunstâncias limitadoras. As reflexões aqui apresentadas são fruto de uma leitura, até certo ponto livre, do filme Dogville, do cineasta dinamarquês Lars Von Trier, leitura iluminada, sobretudo, pela filosofia da educação de Paulo Freire. 0 objetivo é provocar professores, pesquisadores e interessados pela docência a refletirem sobre como se pode, progressivamente, humanizar a educação com vistas à construção de conhecimentos que culminem na prática da liberdade, como proposto pelo pensador brasileiro aqui mencionado.

\section{PALAVRAS-CHAVE}

Condição Docente. Lars Von Trier. Paulo Freire. 


\section{ABSTRACT}

The purpose of this essay is to raise issues considered relevant to the teaching practice which intendeds to be liberating, taking into account the teaching condition, with all its potentialities and limiting circumstances. The reflections presented here are the result of a somewhat free reading of the film Dogville, by the Danish filmmaker Lars Von Trier, a reading illuminated mainly by the Paulo Freire's philosophy of education. The goal is to provoke teachers, researchers and people interested in teaching to reflect on how one can, progressively, humanize education with a view to building knowledge that culminates in the practice of freedom, as proposed by the Brazilian thinker mentioned here.

\section{KEYWORDS}

Teaching condition. Lars Von Trier. Paulo Freire.

\section{RESUMEN}

Este trabajo pretende plantear cuestiones consideradas relevantes para la práctica docente, que intente ser liberadora, teniendo en cuenta el estado de la enseñanza, con todas sus circunstancias potenciales y limitantes. Las ideas presentadas aquí son el resultado de una lectura libre de la película Dogville, del director Lars Von Trier, iluminada, sobre todo, por la filosofía de la educación de Paulo Freire. El objetivo es llevar a los profesores, investigadores e interesados en enseñar a reflexionar sobre cómo podemos humanizar progresivamente la educación con el fin de construir el conocimiento que culmine en la práctica de la liberación, según lo propuesto por el pensador brasileño mencionado aquí.

\section{PALABRAS CLAVE}

Condición docente. Lars Von Trier. Paulo Freire. 


\section{INTRODUÇ̃̃̃o}

O cinema e todas as artes tornam a vida mais vivível e iluminam a forma como pensamos as nossas práticas e concepções. É a partir dessa convicção que desenvolvemos o presente ensaio, fruto de um exercício de reflexão sobre a condição docente a partir do filme Dogville, dirigido pelo cineasta dinamarquês Lars von Trier. As ideias aqui desenvolvidas são pessoais e não se fundamentam em pesquisas empíricas ou mesmo em análises bibliográficas mais sistemáticas, o que, no nosso entendimento, justifica a opção por chamar este texto de ensaio.

Cabe advertir não ser um profundo conhecedor de cinema - aliás, não ser um profundo conhecedor de nada - nem um estudioso da docência, mas, um professor, e também um apreciador do cinema. A docência, o cinema nos ajuda a vivê-la. Se, por um lado, isso não nos autoriza a escrever como um "crítico profissional" ou como um "cientista", confere-nos, por outro, o direito de pensar nossa condição por meio da fruição fílmica.

Agrada-nos a palavra "condição" para pensar a docência ${ }^{1}$. Consideramos interessante, sobretudo, determinadas acepções desta palavra no dicionário Aurélio da língua portuguesa. Nele, "condição" aparece como "modo de ser", "maneira de viver resultante da situação de alguém”, "obrigação que se impõe e se aceita”, conjunto de "qualidades requeridas como ideais" (FERREIRA, 1999, p. 522). Tais acepções ajudam a elucidar aspectos relevantes da prática do professor, sujeito social condicionado como todos os outros, isto é, nem plenamente livre, nem mecanicamente determinado por estruturas macrossociais. E se, conforme Paulo Freire (1996, p. 21) não há docência sem discência, na dialéti-

1. Inês Assunção de Castro Teixeira (2007, p. 429), parte da etimologia da palavra e entende condição como "ato e ação de criar", mas também como "o estado, o status, a situação de um ser no conjunto de realidades ou de um homem na sociedade", a "situação de um homem na vida social". Para os nossos propósitos neste ensaio, interessa mais este segundo significado da palavra. ca do ensinar-aprender, ao pensar a condição docente, necessariamente se pensa a condição discente.

Mas por que Dogville e não um filme que trate especificamente dos processos de ensino e aprendizagem, por exemplo? Há tantos filmes que retratam a docência, fiel ou caricaturalmente. Basta iniciar uma procura para encontrá-los. Então, repetimos a pergunta: por que Dogville? Exatamente para fugir às especificidades que podem limitar a nossa capacidade reflexiva. A trama do longa-metragem escolhido para o desenvolvimento do que aqui discutimos traz em seu conjunto uma série de circunstâncias que chamaremos de educativas, de momentos em que uns ensinam ao aprender com os outros ${ }^{2}$, ainda que Dogville não seja um filme sobre a docência.

Escrever este texto foi muito prazeroso, e, caso algum professor o leia e sinta-se instigado a pensar a sua condição com o auxílio estético do filme aqui proposto, nosso prazer e o nosso trabalho se revelarão plenos de sentido.

\section{MICROCOSMO DOGVILLE}

A trama do longa-metragem ${ }^{3}$ se passa na pequena Dogville, cidade fictícia dos Estados Unidos, no período da Grande Depressão (a conhecida Crise de 1929). Como recurso estético, Lars von Trier optou por utilizar poucos elementos cênicos: toda a cidade ocupa um espaço ínfimo e não há paredes nas "casas" e nas

2. Paulo Freire (1996, p. 23), parafraseando a sua seguinte afirmação: "Quem ensina aprende ao ensinar e quem aprende ensina ao aprender". Como será possível constatar, todo este texto é perpassado pelo ideário de Freire, autor a partir do qual conseguimos pensar a educação de modo esperançoso.

3. O filme Dogville, originalmente lançado em 2003, é o primeiro longa-metragem do projeto de uma trilogia intitulada EUA - Terra das oportunidades. 0 segundo filme da série, Manderlay, foi lançado em 2005, e o terceiro, Washington, ainda não tem previsão de lançamento. 
demais "construções" 4 . Esse recurso confere ao olhar do espectador a onisciência dos eventos e das ações dos habitantes da cidade - nossos olhos veem até mesmo o que os poucos moradores de Dogville gostariam de esconder até de si próprios.

O filme é divido em dez partes: um prólogo e nove capítulos. Um narrador onisciente se encarrega de situar o espectador ao longo dos acontecimentos. No prólogo são apresentados os contornos gerais do modus vivendi dos moradores de Dogville, cidade pobre, onde luxos, mesmo pequenos, não são privilégios de nenhum morador, especialmente naqueles tempos de recessão econômica e de retrocesso social, "tempos difíceis" ${ }^{5}$, na expressão de Chuck, um dos moradores (interpretado por Stellan Skarsgård).

A atmosfera de Dogville é carregada do tédio dos seus moradores que, dia após dia, repetem atividades monótonas, enquanto uns poucos sobrevivem, alimentando a esperança de se mudarem dali para um lugar melhor, como a bela jovem Liz Henson (personagem da atriz Chloë Sevigny), que exclama, em um determinado momento da história: "Assim que meu noivo arrumar um emprego em Boulder, eu sumo!"

Em Dogville, todos se conhecem, cada um sabe da rotina, dos gostos e dos hábitos de todos os outros; os moradores se assemelham em suas crenças, compactuam, ao menos aparentemente, dos mesmos valores, de uma mesma moral, sofrem das mesmas desesperanças. A estrutura social da cidade não é complexa, dado inclusive o seu tamanho ${ }^{6}$. Conforme Astrid Tirel

4. Conforme Astrid Tirel (2004, p. 16), Lars von Trier “dá preferência a um cinema pobre (sem efeitos especiais) que botaria o trabalho do ator no coração do dispositivo".

5. Em todas as falas das personagens ou do narrador onisciente do filme citadas neste texto, fazemos uso literal das mesmas, mantendo, inclusive, certas coloquialidades na escrita, da forma como aparecem nas legendas em língua portuguesa feitas pela Califórnia Filmes.

6. Embora localizada em um país industrializado, onde imperam as leis do capital, existe algo na estrutura de Dogville que permite pensar a coesão social entre os seus moradores nos termos durkheimianos da solidariedade mecânica (DURKHEIM, 1999). De acordo com Tirel (2004, p. 222), uma "solidariedade mecânica está então diante de uma solidariedade orgânica”, embora, nesse conto, a primeira terá razão sobre a segunda.
(2004, p. 216), é na "perspectiva de uma cidade urbana, situada em um sem-lugar e apresentando características comuns a muitas outras cidades, que o cineasta mostra a sua arte". Dogville é microcósmica, uma "miniatura de sociedade" (TIREL, 2004, p. 218).

A vida naquele lugar é marcada por certo arcaísmo, por assim dizer, provocado mais pela pobreza material de seus habitantes que por uma intencionalidade na manutenção de uma estrutura social antiquada. E não seria preferível viver em uma sociedade supostamente obsoleta a se render às seduções do capital, com seus ares e promessas "anti-arcaicos"? Certamente, se a precariedade de certos locais não fosse já obra do poder destrutivo do capital, que colore com luzes e sons as regiões nobres dos grandes centros urbanos e os condomínios de luxo, e mancha de cinza e tristeza os lugares destinados aos despossuídos, como aqueles de Dogville.

Ao recorrer ao conceito bourdieusiano de habitus, que engloba o sistema de disposições incorporadas, duráveis, estruturadas e estruturantes, orientador e gerador das práticas e representações (BOURDIEU, 2003), é possível entender um pouco das concepções e do comportamento dos moradores de Dogville. Trata-se de um grupo social adaptado a uma rotina ditada pela escassez material - inclusive de comida - e que, sem perspectivas reais de abrandamento da situação, lança mão de escolhas do possivel e do provável, isto é, seus membros se conformam em viver o que a vida lhes permite, embora acreditem que são livres e, até certo ponto, responsáveis pelos seus destinos (BOURDIEU, 2007; 2010).

Tal forma de conceberem-se no mundo é fruto da ideologia liberal, que, pautada na noção individualista do "mérito", inculca nos homens a ideia de que a cada um foi dado o que fez por merecer e dissimula a violência desta noção com palavras açucaradas, como "liberdade", "justiça”, "legalidade”, "progresso", "oportunidade". 
As próximas seções destinam-se à leitura do filme, capítulo a capítulo, resultado de minha busca por circunstâncias educativas em sua trama, a partir das quais a condição do professor pode ser pensada.

\section{A CHEGADA A UM MUNDO ESTRANHOE A NECESSIDADE DE ACOLHIMENTO}

A figura central na trama de Dogville e também neste ensaio é Thomas Edison Jr., ou simplesmente, Tom (interpretado por Paul Bettany). Tom é uma espécie de líder intelectual da cidade, um jovem que sonha em ser escritor e que luta pelo "rearmamento moral" de Dogville, nas palavras do narrador do filme. Numa das enfadonhas noites de sua cidade, deitado em um banco a contemplar as estrelas e a vaidosamente imaginar o reconhecimento da sua futura obra literária, Tom se depara com Grace Mulligan, a protagonista do filme (personagem de Nicole Kidman).

Grace chega à cidade pouco tempo depois do ruído de tiros terem sido ouvidos por Tom. Ela é uma jovem bonita, elegantemente vestida, e estava acuada, como se procurasse se esconder de alguém. A configuração do habitus, no caso de Grace, aconteceu em uma atmosfera familiar e social muito diferente daquela de Dogville: moça rica, Grace foi "criada para ser arrogante", em suas próprias palavras. Na verdade, seu pai é o poderoso chefe de um grupo de gângsteres, e Grace era seu braço direito nos "negócios", até que uma briga por motivos banais entre pai e filha a fez fugir em busca de uma nova vida - mas os moradores de Dogville ainda não conhecem a verdadeira história da moça. De fato, ela só lhes será revelada, e de modo trágico, ao final do longa-metragem.

0 primeiro ponto que levantamos como motivo para que seja pensada a condição docente se refere à atitude de Tom em relação a Grace. Mesmo desconfiado de que algo de errado poderia haver com aquela jovem, o que, até certo ponto é normal, dada a forma com que ambos se conheceram, Tom a acalma, pede a ela que não tente fugir pelo caminho perigoso das montanhas que cercam a cidade, leva-a até a sua casa, reparte com ela um pedaço de pão, pouco do que ele e seu pai tinham para comer e ainda consegue convencer os moradores de Dogville, igualmente desconfiados da presença da moça, a permitirem que ela more com eles. $A$ atitude de Tom foi de acolhimento, e acolhimento sem prejulgamentos, ou, na expressão do próprio Tom, de “aceitação".

É bem verdade que Tom se encantara com a beleza de Grace desde o primeiro instante em que a viu, o que poderia revelar outras supostas intenções por trás de seu acolhimento - tendenciosidades das quais os professores, melhor, os seres humanos, por sua condição, não estão livres. De fato, a paixão de Tom por Grace só fará aumentar no decorrer do longa-metragem, assim como a sua dedicação (interessada) pela forasteira. Todavia, deixando de lado a afetividade romântica - e até erótica - de Tom por Grace, o fato é que sua postura nos faz pensar sobre a necessidade de nós professores acolhermos nossos alunos, de nos abrirmos a todas as suas necessidades, de compreendê-los sem julgamentos morais, estéticos, políticos e sociais, de repudiarmos qualquer preconceito de raça, de sexo e de orientação sexual e de lutarmos contra o racismo, o classismo, o moralismo e o sexismo.

Longe de pretender idealizar ingenuamente a docência, isso se torna uma confissão de nossas inclinações antiéticas, de nossos preconceitos, contra os quais precisamos lutar, exercício necessário ao processo de libertação. Sim, nós professores não estamos isentos de demônios internos que podem se manifestar em forma de atitudes de não-acolhimento, tornando-nos refratários ao outro. A grande batalha é para que, em vez alimentarmos esses demônios, possamos exorcizá-los de nossa prática e de nossa vida. Nosso acolhimento deve servir como testemunho aos alunos, para que eles se acolham e recebam com a mesma abertura os professores e demais envolvidos nos processos educativos. 
Depois de apresentar Grace aos habitantes de Dogville, e de obter deles uma permissão condicional para deixá-la morando ali, Tom faz um passeio com a jovem pelas ruas da cidade, explica para a moça quem é cada um de seus moradores, pintando um quadro moral com todas as "virtudes" e com todos os "vícios" de seus conterrâneos. Os vícios são mais pungentes no discurso de Tom, que não deixa de ser depreciativo ao tratar de sua própria cidade, ao que Grace reprende, embora com uma fala carregada de doçura: "Você escolheu um jeito estranho de mostrar a cidade que você ama. Eu só vejo uma bela cidadezinha em meio a montanhas magníficas. Um lugar onde as pessoas têm sonhos e esperanças, até mesmo sob as piores condições".

Agora é Grace quem ensina. Ensina que uma mesma situação pode ser analisada sob diferentes perspectivas, as quais tendem a descortinar realidades ocultas. É possível e necessário que eduquemos os nossos olhares, para que auxiliemos nossos alunos a educarem os seus. E Grace precisará provar àquela gente que é merecedora de viver em Dogville. A melhor forma de provar esse merecimento, conforme um plano traçado por Tom será retribuindo o "favor" de cada um dos moradores com trabalhos cotidianos braçais, a princípio simples e pequenos... Mas só a princípio.

\section{QUE É PRECISO FAZER?}

Na luta por sua permanência em Dogville, Grace se oferece a ajudar os moradores em seus trabalhos domésticos. A moça com "mãos de alabastro", mãos brancas e suaves que nunca precisaram pegar peso ou executar atividades que as calejassem ou as enfeassem, agora precisava se despir de toda a sua vaidade em nome de uma necessidade maior. Viver é mais importante para a jovem, ainda que isso pudesse trazer consequências, como a sua desfiguração física - afinal, os outros moradores há muito já haviam aberto mão da vaidade em função da sobrevivência e Grace precisava se tornar um deles, como popularmente dito.
Mas é interessante notar que a bela nova moradora parece não se incomodar com as mudanças impostas por sua situação. Pelo contrário, certo ar de satisfação passou a reluzir em seu rosto, como se pela primeira vez em sua vida ela percebesse o quanto seria bom deixar para trás as frivolidades oriundas de seus luxos. Grace tendia a acreditar que ali, naquele lugar pobre, no meio daquela gente simples, estaria a tão buscada felicidade.

No entanto, a jovem tem dificuldade, num primeiro momento, em fazer aquelas pessoas aceitarem a sua ajuda. Motivos não faltaram para a recusa dos moradores, apegados por demais às suas tarefas cotidianas. Chegaram até a dizer que não havia nada a se fazer em Dogville, que se Grace executasse trabalhos que são deles, apenas o ócio absoluto lhes restaria. É possivel que aquela gente sentisse outro tipo de vaidade, até mesmo orgulho ou receio de que a moça os auxiliasse. Por desconfiança ou presunção, ainda não haviam se aberto à nova moradora.

Mais uma vez a intercessão de Tom foi eficaz: ele sugeriu aos seus conterrâneos que Grace fizesse trabalhos que não precisavam ser feitos. Assim os moradores poderiam continuar os trabalhos costumeiros enquanto a forasteira faria o que eles não estavam acostumados a fazer. Acordo feito. Grace então começa a fazer o que "não" era necessário fazer, como por exemplo, levar uma jovem deficiente ao banheiro. Não era necessário? De fato, June (personagem interpretada por Shauna Shim), a jovem deficiente, ficava em casa o dia todo sozinha enquanto Olivia (interpretada por Cleo King), sua mãe, trabalhava, e o uso de fraldas dispensava a mãe do trabalho de ajudar a jovem fazer as suas necessidades, num exemplo de total desumanização da filha pela própria mãe, ainda que de modo um tanto inadvertido.

Esse e outros trabalhos realizados por Grace desmascararam o comodismo alienante daquela gente. A situação daqueles homens e mulheres os impedia de enxergar que muito do que não é feito porque se pen- 
sa que não é preciso fazer, na realidade, tende a ser o essencial, o que dignifica e humaniza. 0 exemplo de Olivia e June mostra, conforme Luiz Gustavo Françoso Pereira da Cruz (2011, p. 53), que de fato não há o que Grace possa fazer de realmente necessário em Dogville, mas "rapidamente o supérfluo se torna importante. Qualquer tarefa antes impensável e inútil pode tornar-se necessária”. Assim, conforme Tirel (2004, p. 220), a atividade de Grace passa a ser "indispensável e reconstitui o ligamento social da comunidade”.

E quantas coisas nós professores não fazemos, porque acreditamos que não precisamos fazê-las? A nossa condição de professores exige de nós um envolvimento cada vez maior com ela, pelo nosso bem e pelo bem de nossos alunos. Existem autoridades e grupos supostamente responsáveis por fazer da docência uma atividade humanizada, mas eles pouco ou nada fazem em prol da educação. Essa outra circunstância educativa do filme Dogville nos dá pistas sobre como podemos incrementar a nossa luta, fazendo por nós mesmos o que certos setores pensam ser desnecessário.

\section{ESTAMOS CEGOS? FOMOS CEGADOS?}

Um personagem especialmente interessante de Dogville é Jack McKay, interpretado pelo ator Ben Gazzara. Trata-se de um idoso que perdeu a visão, mas que tenta, a todo custo, esconder a sua cegueira de seus conterrâneos. Ele vive só em sua casa, cujas janelas são hermeticamente fechadas por cortinas longas e escuras. Quase não vai à rua, e quando o faz, caminha sem problemas pela cidade, pois a conhece de memória em todos os detalhes, o que, para ele, é o suficiente para disfarçar a perda de sua visão.

Todavia, as pessoas da cidade conhecem bem a situação de McKay, mas por conveniência ou respeito, preferem fingir que não conhecem. Ninguém o visita, na tentativa de não obrigá-lo, ainda que de modo não intencional, a expor a sua cegueira, e quando ele é vis- to pela rua seus conterrâneos não ousam colocá-lo em situações que pudessem desmascarar sua deficiência.

Grace, continuando a empreitada por sua permanência em Dogville, vai até a casa desse senhor, a fim lhe oferecer ajuda, mas seus favores são aceitos por ele somente depois de alguma insistência da moça. Após longas conversas sobre eventos passados da cidade, Grace, que desde o primeiro momento havia percebido a cegueira cuja possibilidade de revelação tanto incomodava a McKay, resolve fazê-lo encarar a sua condição: ela abre as cortinas para que ambos “vejam” a luz, causando naquele homem uma profunda tristeza.

Várias interpretações dessa outra circunstância educativa de Dogville poderiam ser feitas, mas preferimos analisá-la como uma metáfora de um tipo de cegueira mais grave: uma cegueira social, que nos impede de enfrentar as mazelas do mundo e da vida porque preferimos fingir que não as vemos ${ }^{7}$. McKay não podia fugir de sua cegueira, e talvez soubesse que seus conterrâneos também tinham conhecimento dela, mas uns e outros camuflavam a situação com comportamentos socialmente aceitáveis, mas pouco edificantes e libertadores.

A condição docente exige de nós, professores ainda que exista a possibilidade de falharmos no processo, humanos que somos -, que arranquemos as vendas de nossos olhos, que a artificialidade de determinadas relações sejam expostas em nome de atitudes corajosas, de enfrentamento de ideologias e de grupos sociais e políticos que nos alienam em nome da injustiça ardilosamente vestida de meritocracia.

A coragem que falta a McKay de enfrentar a sua condição é a mesma que muitas das vezes nos falta para que arrostemos a nossa. Há setores que lutam para preservar determinadas relações, por isso nos cabe desnaturalizá-las, confrontá-las, estranhá-las. Cabe a nós a atitude de Grace: um impetuoso des-

7. É possível aproximar esta discussão das que emergem do Ensaio sobre a cegueira, de José Saramago (2008). 
cortinar de nossa realidade - mesmo cientes de que, como virá a ocorrer com a personagem central do longa-metragem, a luta possa ser vã, inclusive a luta travada contra nosso próprio eu-docente, por isso mesmo é uma luta.

\section{TUDO EM PAZ... POR ENQUANTO!}

Dos nove capítulos do filme, o mais curto é o quarto, com exatos seis minutos e vinte segundos de cenas. Por isso mesmo é possível que propositalmente Lars von Trier tenha intitulado esse capítulo de Happy times in Dogville, ou Bons tempos em Dogville, na legenda em português. Grace finalmente fora aceita de modo amigável pelos moradores da cidade.

Seus serviços eram-lhes agradáveis, tanto que todos concordaram em dar um "salário" à jovem, ou seja, pequenas quantias em dinheiro pelos seus préstimos, o que levou Grace a paulatinamente comprar uma coleção de sete bonecos de porcelana que há muito acumulavam poeira na única loja da cidade. Grace até ganhou uma "casa" para morar: um velho moinho desativado. Contudo, a visita de um agente policial começou a abalar a estabilidade duramente conquistada. Um cartaz de procura com a foto e o nome de Grace foi afixado pelo agente em um local bastante visível. A presença da moça parecia ser uma ameaça àquela gente. Novos dias estavam por vir...

\section{PAZ TEMPORÁRIA E VIOLÊNCIA HORIZONTAL}

Quatro de julho, dia em que se celebra a Independência dos Estados Unidos da América. Todos os moradores de Dogville se reúnem para uma festa comemorativa. Grace fora, finalmente, acolhida. De modo recíproco, ela passara a amar aquela cidade. 0 próprio Jack McKay, cuja cegueira havia sido exposta por Grace, teria muitos motivos para odiá-la, mas, vendo em sua atitude um ato de verdade e libertação, proferiu um discurso durante o banquete comemorativo do Independence Day que ilustra a forma como a nova moradora passou a ser vista:

Este ano, eu não trouxe nenhuma anotação, pois não vou fingir que posso ler. 0 que me traz à questão que quero abordar. É o seguinte: você, Grace, faz de Dogville um lugar maravilhoso para morar. Na verdade, alguém encontrou o rabugento Chuck na rua e ele estava sorrindo. Eu nunca vi o seu sorriso, Grace, mas aposto que posso descrevê-lo. Pois ele tem todas as cores refratadas do prisma mais brilhante do mundo. [...] Estamos orgulhosos de tê-la conosco. E nós agradecemos por ter se revelado a nós. (Levanta um brinde) A você, Grace. Pode ficar conosco o quanto quiser.

0 primeiro cartaz de procura afixado pelo agente policial em Dogville trazia a palavra "Desaparecida" (Missing) para se referir a Grace, contudo, durante o banquete, quando tudo parecia caminhar bem, o agente retorna à cidade com um novo cartaz, agora com a palavra "Procurada" (Wanted) acima da foto da jovem, e a oferta de uma alta recompensa em dinheiro para quem a encontrar e denunciar. 0 acréscimo da expressão "perigosa" na fala do agente agravou os seus dizeres.

Os moradores parecem alimentar um tipo de fidelidade à jovem Grace, a ponto de nenhum deles fazer a sua denúncia, mesmo sabendo da recompensa e dos riscos que supostamente corriam com a presença da fugitiva. Contudo, Grace deverá oferecer àquela gente trabalhos proporcionais ao aumento do risco que sua presença oferece, numa economia de troca cujos termos incluem a redução do já ínfimo "salário" da moça. Em termos marxianos, poder-se-ia dizer que o aumento da quantidade de horas de trabalho, somado à sua intensificação e à redução do salário de Grace maximizaram a extração da mais-valia, tanto da relativa quanto da absoluta (MARX, 1983; 1996; ROSSO, 2008).

Grace então inicia uma rotina ainda mais árdua, pois um "injusto horário de trabalho" the havia sido 
"imposto", de acordo com o narrador do filme, o que passa a esgotá-la física e psicologicamente ao final de cada dia. Como se isso não bastasse, a jovem começa a ser hostilizada pelas mulheres da cidade e vista como um mero objeto de desejo sexual pelos homens, que começam a se sentir no direito de exigir dela que os beije ou que ela lhes permita algumas intimidades, como o caso do próprio McKay, que tentou passar a mão em suas pernas.

A circunstância educativa aqui é a que nos pode levar a refletir sobre a posição dos opressores e dos oprimidos na estrutura social. O povo de Dogville é um povo oprimido, vítima de uma ordem social que desfavorece aos pobres em tudo. Grace, por sua vez, é uma opressora que se vê, por força dos acontecimentos, no lugar inverso, ou seja, ela se torna uma oprimida. 0 mais grave nisto é que, embora Grace tenha escondido dos moradores a sua origem criminosa, e apesar de considerar a insegurança que sua presença trazia àquela gente, é injustificável a violência imposta pelos moradores à sua pessoa, visto estarem todos na mesma situação de opressão.

Trata-se, nesse caso, de uma violência horizontal (FREIRE, 2011, p. 68), isto é, uma injustificável violência imposta pelos oprimidos a outra oprimida. Grace é sim, uma criminosa, mas o povo de Dogville ainda não sabe disto, ao menos não tem certeza, o que torna ainda mais violento aquele comportamento.

É nosso dever ético, enquanto professores, combater todas as formas de violência, seja ela física, psíquica ou simbólica, sobretudo a violência horizontal, latente em nós, mas da qual devemos nos conscientizar para que não nos tornemos opressores, tanto nos processos educativos como na vida social, de modo abrangente. Conhecer a fundo as nossas práticas faz com que se desvelem as estruturas de dominação em nós internalizadas, e que podem se manifestar, mesmo que inadvertidamente, em nossa relação com o outro.

\section{A FRAGILIDADE DO OUTRO NÃO NOS DÁ O DIREITO DE OPRIMI-LO AINDA MAIS}

A busca das autoridades policiais por Grace passa a receber os reforços do Federal Bureau of Investigation (FBI), o que aumenta os temores dos moradores da cidade, cada vez mais divididos entre o dever legal de denunciar à jovem e o receio de perderem para as autoridades aquela que passou a ser uma quase escrava de todos.

Uma das cenas mais marcantes de Dogville, ao menos em nossa opinião, é a cena em que Chuck, guiado por seu desejo sexual, chantageia Grace: ele ameaça entregar ao FBI um lenço, contendo as iniciais da jovem, caso ela não o trate com "respeito", leia-se, faça sexo com ele. Grace reluta, mas a força física de Chuck somada ao medo da jovem faz desfalecer toda a sua capacidade de resistência. Grace é violentada sexualmente dentro da casa daquele homem, enquanto sua mulher e seus filhos não estavam presentes. De acordo com o narrador do filme, outra vez, "Grace havia escapado da polícia com a ajuda dos habitantes de Dogville" (Grifo nosso).

A cada dia a vida de Grace em Dogville fica mais difícil. 0 comportamento hostil dos moradores da cidade converte-se em um tipo de paternalismo cruel: todos se sentem no direito de exigir cada vez mais da moça em troca de sua "proteção". Mas enquanto a "protegem" da polícia, aquelas pessoas passam a violentá-la psíquica, física, moral e sexualmente. Até mesmo as crianças da cidade, sobretudo o menino Jason (personagem do ator mirim Miles Purinton), começam a tratar a fugitiva de modo a reproduzir aquilo que percebem nas atitudes dos adultos. 0 clima é de intensa desumanização de todas as partes.

O que se pode depreender daqui como circunstância educativa refere-se à "solidariedade" dos moradores de Dogville para com Grace. Na compreensão 
daqueles homens, mulheres e crianças, mantê-la "protegida" da polícia confere-lhes o direito de explorá-la a ponto de arrancar da jovem a sua dignidade e a sua humanidade. Para analisar esta situação, evoco novamente Paulo Freire (2011, p. 49), que escreveu: "Solidarizar-se não é ter a consciência de que explora e 'racionalizar' sua culpa paternalisticamente. A solidariedade, exigindo de quem se solidariza, que 'assuma' a situação de com quem se solidarizou, é uma atitude radical' (Grifo nosso).

A condição docente exige que nós professores sejamos radicais em nossas práticas. $\mathrm{E}$ isto deve ser entendido como a busca profundamente ética de uma conduta radicalmente solidária para com os nossos alunos e para com os nossos companheiros de profissão. Qualquer ação que possa apresentar o mínimo de chantagem, traição e paternalismo deve ser excluída dos processos educativos em nome da luta por práticas horizontalizadas e humanas. Cabe-nos uma autovigilância constante contra a verticalidade e a desumanização, que sempre podem aparecer mascaradas de bondade.

É necessário aqui pelo menos um esclarecimento. As exigências das quais tratamos insistentemente, longe de serem prescritivas, normativas, frias, impositivas, pretendem ser, na realidade, uma exortação à autenticidade, à humanidade na prática docente. Não há nenhum traço de originalidade, tampouco pretensões de ineditismo no que defendemos. Apenas siguimos os passos de Freire (1996), que tão bem descreve a condição docente, ilumina os caminhos necessários a se percorrer e conclama a todos para uma prática educativa libertadora.

\section{COISIFICAÇ̃̃O EM NOME DA HONRA?}

A exploração sexual se intensifica a partir do capítulo sete do filme. Os homens de Dogville, jovens e velhos, passam a exigir de Grace que ela sacie os seus desejos. E assim, noite após noite, ela recebe em seu local de moradia homens casados e solteiros, e, sem direito de recusa, entrega-se para que eles façam sexo com ela, que ainda precisa guardar segredo, por vergonha de sua situação e por medo das esposas traídas.

Chuck foi o primeiro a abusar de Grace e o que passou a cometer os abusos de modo mais frequente. Em troca do seu silêncio, ele exige a submissão sexual quase diária de Grace. Chuck é casado com Vera (interpretada por Patricia Clarkson) e pai de sete filhos pequenos. Numa das manhãs em que Chuck forçava Grace a se relacionar sexualmente com ele em meio a uma plantação de maçãs, Martha (personagem de Siobhan Fallon), avista-os e conta a Vera o que viu. Acreditando ter sido o marido seduzido por Grace, Vera vai à noite à casa da jovem, no intuito de "educá-la".

Vera começa, então, a torturar psicologicamente a jovem Grace: a esposa traída quebra, um a um, os sete bonecos de porcelana a custo adquiridos pela moça. Aquelas sete miniestátuas eram o seu bem maior em Dogville, objetos materiais que, como defende Leonardo Boff (1979, p. 11), tornam-se "sinais e símbolos do encontro, do esforço, da conquista, da interioridade humana" (grifo nosso); em uma palavra, tornam-se sacramentos. É importante esclarecer que, de acordo com o autor, os sacramentos não se relacionam, necessariamente, com religiosidade ou com instituições religiosas: "Os sacramentos não são propriedade privada da sagrada Hierarquia. São constitutivos da vida humana" (BOFF, 1979, p. 14-15. Grifo nosso). Sendo, "por essência, evocação de um passado e de um futuro, vividos num presente" (BOFF, 1979, p. 13), as miniestátuas remetiam Grace a momentos de paz já vividos e a momentos que ela sonhava ainda viver ${ }^{8}$.

Relacionando, sarcasticamente, a sua "forma de educar" com a filosofia do estoicismo ${ }^{9}$ da Grécia e

8. Aqueles pequenos bonecos despertavam em Grace o que Marilena Chauí (1997, p. 117) chamou de imaginação evocadora, a qual "presentifica o ausente por meio de imagens com forte tonalidade afetiva”.

9. Um interessante trabalho sobre o estoicismo greco-romano é o de Ana Filipa Isidoro da Silva (2008). Para os que apreciam ir diretamente “à fonte”, sugerimos a leitura de Lúcio Aneu Sêneca (1985). 
Roma Antigas, que buscava levar os homens ao alcance da imperturbabilidade da alma, mesmo nos momentos extremos da vida, Vera diz a Grace que se ela não chorasse ou esboçasse reação após a quebra do primeiro boneco, os demais seriam poupados. Obviamente, Grace chora desesperadamente, pois aqueles bonecos eram objeto de imensa afetividade, estimados pela jovem como se fossem seres humanos, mais que isto, como se fossem seus filhos. Conforme o narrador do longa-metragem

\begin{abstract}
Em toda a vida, Grace tinha prática em esconder as emoções e não achou que seria difícil controlá-las agora. Mas a porcelana espatifada no chão era como tecido humano a se desintegrar. Os bonecos eram o resultado do seu encontro com a cidade. Eles eram a prova de que, apesar de tudo, seu sofrimento havia criado algo de valor. Grace não aguentava mais. Pela primeira vez, desde a sua infância, ela chorou. (Grifo nosso).
\end{abstract}

É quase dispensável escrever aqui o quanto quaisquer formas de repressão, ameaça, tortura, aliciamento e humilhação, devem ser rejeitadas, denunciadas e abolidas por nós, professores. E quantos casos como esses são conhecidos por nós! ${ }^{10}$ De forma alguma, mesmo que de modo "bem intencionado" ou em nome de uma atualização arbitrária do estoicismo, atitudes semelhantes à de Vera podem ser aceitas na prática docente, e em nenhum outro espaço da vida humana. Não estamos considerando aqui a natural raiva da personagem traída, o que, no caso do filme, poderia justificar atitudes extremas como formas de vingança. 0 que fazemos é uma leitura desta circunstância educativa, como exemplo radical e paradigmático para dizer que os envolvidos nos processos educativos precisam ser tratados e tratar a todos com humanidade e respeito à integridade física e psicológica que lhes é merecida.

Ainda no capítulo de número sete, Tom planeja a saída de Grace da cidade. 0 encarregado da tarefa

\footnotetext{
10. Os próprios casos de discriminação nas salas de aula podem ser mencionados como exemplos. A propósito, o termo "discriminação" cabe melhor para compreendermos a real dimensão desta forma de violência do que a expressão "bullying", anglicismo pouco corajoso, que acaba por funcionar de modo eufemístico.
}

seria Ben, pobre caminhoneiro interpretado pelo ator Žlejko Ivanek. O plano era simples: ao sair da cidade com um carregamento de maçãs, Ben esconderia Grace em meio à carga e a deixaria em alguma cidade o mais distante possível de Dogville, onde Tom a encontraria posteriormente para, juntos, iniciarem uma nova vida - trata-se do sonho romântico de que tudo termine bem para o herói e a heroína do filme.

Esperançosa e até certo ponto feliz, Grace se esconde entre as maçãs cobertas por uma lona, e o vetho caminhão parte de Dogville. Em um dado momento, Ben, inflamado por seu desejo por Grace embora envergonhado em sua timidez característica, para o caminhão e exige que a moça faça sexo com ele. Um suposto grande número de policiais no caminho torna o favor mais "caro", e Grace não tem escolha. Embora triste e decepcionada, Grace consegue dormir e, ao acordar, surpreende-se ao saber que estavam de volta a Dogville, onde Ben conta a todos sobre a tentativa de fuga da jovem.

A desumanização de Grace - marca da igual desumanização do povo de Dogville - chega ao seu extremo quando da criação de um "mecanismo de prevenção de fuga" elaborado por Bill Henson (personagem de Jeremy Davies): a moça é acorrentada a uma pesada roda de ferro que dava a ela uma mobilidade mínima, apenas o suficiente para que pudesse continuar executando os seus trabalhos diários, cada vez mais intensificados, agravados por olhares de ódio ou de falsa piedade dos moradores.

Um sino é colocado em seu pescoço, para que, pelo barulho do seu tanger, todos saibam onde ela está, caso tente fugir outra vez. As explorações sexuais também se intensificam: cada vez mais Grace é abusada, sem o direito de reclamar e ainda tendo de suportar as crianças tocando o sino da "Casa da Missão" - a igreja que aguardava a chegada de um padre que nunca vem - toda vez que um homem entra em seu local de moradia, toque de sino que funciona como uma verdadeira marca sonora de proscrição que 
explicita o (falso) moralismo da gente de Dogville ao expor a submissão da jovem fugitiva como se essa fosse a mais impura das imoralidades ${ }^{11}$.

Haverá os que considerarão exagero de nossa parte relacionar atos tão extremos de Dogville com a educação. Mas pensemos em quantos casos de exploração sexual contra crianças e adolescentes povoam os veículos de comunicação de massa, quase diariamente - e esses podem ser apenas a ponta do iceberg. Pensemos no assédio moral que tantos menores sofrem, na má qualidade da estrutura física de tantas escolas, na merenda que deixa de alimentar estômagos famintos de crianças pobres para engordar os bolsos dos corruptos... Sim, violências como as vividas por Grace assolam a vida escolar e coisificam ${ }^{12}$ docentes e discentes.

\section{TUDO EM PAZ NOVAMENTE?}

Toda a verdade é revelada por Grace aos moradores de Dogville em uma reunião convocada por Tom na “Casa da Missão". Então, a "estrangeira” que "faz parte do grupo sem realmente fazer parte dele”, nas palavras de Tirel (2004, p. 220), mostra-se abertamente, mas também expõe as misérias daquelas pessoas, o que não pode deixar de incomodar os seus anfitriões/exploradores.

A jovem passa a ser vista como um incômodo e Tom é considerado culpado pela permanência em Dogville daquela que desequilibrou a "ordem" da cidade. Movido pela raiva de seu povo, todavia conferindo a seus condenadores certa dose de razão, Tom vai até a casa de Grace reivindicá-la o que ele pensa the ser de direi-

\footnotetext{
11. Há, no trecho mencionado, interessantes relações a se fazer com a canção Geni e o zepelim, de Chico Buarque de Hollanda (1982), como, por exemplo, a instrumentalização da vida sexual de uma personagem em função de interesses coletivos, bem como o falso moralismo disfarçado de piedade e prática de "bons costumes".

12. A palavra, mais uma vez, é de Paulo Freire (2011), que a usa diversas vezes em sua obra como sinônimo de reificação do homem, de sua desumanização.
}

to por ter recebido a antipatia de seus conterrâneos e pelo fato de tê-la "ajudado" durante todo o tempo: ele deseja ter uma noite de sexo com ela, ao que a jovem recusa. Com efeito, Grace parecia gostar de Tom, e desejava ficar com ele "em liberdade", e não o amar como todos os outros a "amam”, por meio de ameaças.

Tom: Você está fria, Grace. Eu rejeitei todas as pessoas que conheço por sua causa. Será que não poderia me dar isso para amenizar a minha dor? Todos aqui já tiveram o seu corpo, menos eu. E somos nós que estamos apaixonados!

Grace: Meu querido Tom, pode ter-me se quiser. Faça como os outros. Me ameace, diga que vai me entregar para a polícia ou para os gângsteres e prometo que vai conseguir o que quiser. Eu confio em você. Talvez não confie em si mesmo. Talvez esteja tentado a agir feito os outros e me forçar. Talvez por isso esteja nervoso.

Irado, embora dissimulando sua ira perante Grace, Tom mostrará sua face "prática". Com efeito, logo no capítulo I, bem no início do filme, os gângsteres haviam dado a ele um cartão com um número de telefone para contato, caso Grace por ali aparecesse. Tom conversou com o chefe do grupo, sem saber que se tratava do pai de Grace, ouvindo desse homem as seguintes palavras: "Fique com o meu cartão. Se, por acaso, vir uma estranha, me ligue. Eu posso the oferecer uma boa recompensa".

Embora houvesse, naquele momento e durante certo tempo, guardado segredo, o fato é que a raiva aliada ao efeito produzido pela palavra "recompensa" levaram Tom a agir de modo diverso: os gângsteres são acionados, Tom e todo o povo de Dogville se tornam estranha e dissimuladamente simpáticos com Grace. Eles aguardavam o grande desfecho da história, em que ela seria entregue a um grupo que a mataria e, quem sabe, daria a eles uma recompensa em dinheiro. É a pura venalidade da vida, na concepção daquele povo desumanizado e desumanizador.

Essas cenas marcam um momento crítico do filme de Lars von Trier, momento em que toda e qualquer esperança se esvai, em que a dignidade da vida humana 
é colocada abaixo de interesses desumanizantes e do desejo de retorno ao antigo status dogvilliano. Como circunstância educativa, é este o ponto que deve despertar a capacidade crítica e reflexiva dos professores: nada pode justificar um retorno a situações degradantes após momentos de crise. Ao contrário, a crise deve servir de ensejo para a completa refutação e para a não aceitação das violências. E jamais a vida pode ser vista como objeto venal, como uma "coisa" que pode ser trocada por outra "coisa". Todo educador deve, antes de tudo, ser um filantropo, uma amante da vida humana, na radicalidade do termo.

\section{A MUDANÇA SERIA POSSÍVEL}

Os gângsteres chegam a Dogville. Ao verem a animalização total pela qual havia passado a jovem Grace, eles são tomados por uma grande indignação, fazem com que a livrem da corrente e conduzem-na ao veículo onde estava seu pai já a sua espera.

A conversa entre pai e filha é tensa apenas nos primeiros instantes do reencontro. Poucas palavras depois, Grace já havia percebido que "as diferenças entre as pessoas de casa e as de Dogville" eram "mais amenas do esperava", o que a leva a optar por reconciliar-se com seu pai e retornar para a casa, mas agora com a garantia de que terá mais "poder".

A revolta contra o povo de Dogville culmina em violência extrema: todos os moradores são exterminados após a conclusão à qual chega Grace de que o "mundo ficará muito melhor sem esta cidade". Tom é o último a morrer, com uma bala disparada pelas “mãos de alabastro" de Grace. Apenas Moisés, o cão, é poupado da morte. A família foge daquele lugar e o filme se encerra com fotos reais de violência contra tudo o que mais humaniza as pessoas: sua dignidade.

Do encerramento do filme é possível depreender alguns aspectos interessantes acerca do povo de Do- gville. Era um povo pacato, por assim dizer, mas que sempre se manteve a sombra de um comodismo incapaz de retirá-lo da inércia de uma vida sem questionamentos e sem confrontos com os seus próprios dilemas e misérias. Pelo contrário, aquela gente preferia fingir que não via os seus problemas, buscando a todo custo a manutenção de um status quo moral bastante confortável (alienante, na realidade) a realmente encarar os seus demônios, no fito de resistir a eles. Grace mostrou-lhes os seus demônios, mas eles preferiram não exorcizá-los. Não era a moça que os incomodava, mas a coragem dela.

Coragem é algo que jamais pode faltar a nós professores. Coragem para lutarmos cotidianamente, com as nossas armas, contra a opressão, contra a miséria, contra a injustiça. Coragem para entrarmos em diálogo constante e autêntico com nossos alunos, com nossas alunas e como nossos companheiros de profissão e de condição, os professores. Coragem para acreditarmos que a educação pode sim ser transformadora, o que exige a coragem para vencermos o desânimo que tanto nos impede de perspectivar nossa atuação de um modo novo, iluminada pela luz do desejo de mudança.

Grace representa, nesta leitura do longa-metragem, exatamente a coragem e o sonho. E o grande paradoxo de Dogville é que, justamente uma criminosa, uma opressora, movida pela busca de sua autotransformação naquele lugar tão propício a isto é que vai, mesmo que em vão, tentar transformar-se, orientando para a transformação, mais uma vez no movimento dialético do modificar-se a si na busca pela modificação do todo.

Que o fracasso da construção de uma sociedade justa em Dogville não seja entendido como o arquétipo do real. Pelo contrário, esse filme pode nos levar a refletir sobre modos inovadores de intervenção na realidade sem que nos desestimulemos. Crer na impossibilidade da transformação social é uma tentação à qual não podemos ceder. 


\section{UM CONVITE A NOVAS REFLEXÕES}

Todo o empenho neste texto foi o de destacar momentos do filme Dogville que servem para ilustrar e levantar reflexões sobre a condição docente. Esses momentos, chamados de circunstâncias educativas, dizem respeito a cenas do longa-metragem nas quais processos informais de ensino e aprendizagem aparecem de forma não polarizada: ora uns ensinam enquanto outros aprendem, ora os lugares do "professor" e do "aprendiz" se invertem e ora ainda ambos se confundem na dialogicidade ${ }^{13}$ do ensinar-aprender. Esses processos não acontecem sem tensões e conflitos, o que serviu de referência e motivo para o exercício reflexivo aqui proposto.

Obviamente, o reduzido espaço deste texto é insuficiente para uma discussão mais aprofundada sobre um tema tão complexo como o do ato de ser professor. Mesmo as discussões sobre o filme Dogville necessitariam de muito mais fôlego para serem tratadas de modo mais consistente e aprofundado ${ }^{14}$. Contudo, estas páginas serviram para que, ao menos minimamente, ficassem sugeridas algumas questões que precisam ser encaradas por professores, alunos, licenciandos, elaboradores de políticas públicas e pesquisadores numa tentativa constante de superação dos problemas referentes à educação, de um modo geral.

Pensar tais questões com ludicidade é ainda mais instigante, e Dogville é um potencial instrumento para esta tarefa. Concordamos com Tirel (2004, p. 215), na defesa de que o cinema tem participação

13. A respeito da dialogicidade, essência da educação como prática da liberdade, conferir Paulo Freire (2011, p. 107-166).

14. Como faz, por exemplo, Evelise Guioto de Souza (2007). Um lugar-comum pode ser evocado para mais uma observação pontual: uma obra de arte ou uma produção cultural nunca esgota aquilo que pode nos provocar a refletir. Perdemos as contas de quantas vezes assistimos ao filme Dogville nos últimos anos, mas sempre ao revê-lo, descobrimos sendas não traçadas, caminhos não percebidos, quase não vistos por nossos olhos nas vezes anteriores. Sabemos que o rever e rever e rever sempre perceberemos o novo, desde que queiramos vê-lo, que nos abramos a ele. Por isso, interessa-nos tanto que os educadores o vejam, para, com os seus olhos, completarem e corrigirem os meus. "na renovação do pensamento das sociedades propondo produções nas quais as implicações vão além das questões estéticas atribuídas ao espetáculo ${ }^{15}$ para interrogar os atores sociais".

Quais são as condições necessárias à construção de uma educação autêntica, para se colocar assim, condições que podem ser pensadas a partir do filme Dogville? Acolhimento sem prejulgamentos, envolvimento, humanidade, busca de perspectivas originais para a leitura da realidade, abandono do comodismo, estranhamento e desnaturalização de determinadas relações, repúdio e combate a todas as formas de opressão e violência, autovigilância contra as atitudes paternalistas e contra as relações sociais verticalizadas, respeito à integridade física e psíquica das pessoas, luta contra a venialidade do que não pode ser tratado como venal, coragem para arrostar as misérias da condição docente/discente, luta contra o revanchismo e o senso de vingança, entre tantas outras que poderiam estender esta lista.

Por mais degradantes que possam ser as circunstâncias que envolvem a atividade docente, é necessário que nós, professores, internalizemos a ideia de que os condicionantes de nossa prática não devem ser motivo de desânimo, visto que, se não podemos mudar a situação da educação de modo plenamente livre e deliberado, como num passe de mágica, é bem verdade que nós não somos ventríloquos ou marionetes de uma força maior que a nossa. O caminho é longo, árido e doloroso, mas é necessário que o percorramos. Pensar sobre ele já é dar um primeiro passo.

\section{REFERÊNCIAS}

\section{BOFF, Leonardo. Os sacramentos da vida e a vida}

dos sacramentos: ensaio de teologia narrativa. Petrópolis: Vozes, 1979.

15. Espetáculo, aqui, no sentido dado por Guy Debord (1997). 
BOURDIEU, Pierre. Esboço de uma teoria da prática. In: ORTIZ, Renato (Org.). A Sociologia de Pierre

Bourdieu. São Paulo: Olho d’Agua, 2003. p.39-72.

BOURDIEU, Pierre. A distinção: crítica social do julgamento. São Paulo: Edusp; Porto Alegre: Zouk, 2007.

BOURDIEU, Pierre. Futuro de classe e causalidade do provável. In: NOGUEIRA, Maria Alice; CATANI, Afrânio (Org.). Pierre Bourdieu: Escritos de educação. Petrópolis: Vozes, 2010, p.81-126.

CHAUI, Marilena. Convite à filosofia. São Paulo: Ática, 1997.

CRUZ, Luiz Gustavo Françoso Pereira da. Dogville, de Lars von Trier, e a utilização da obra de Brecht como modelo. 2011. (Dissertação de Mestrado) - São Paulo: Escola de Comunicação e Artes, Departamento de Artes Cênicas da Universidade de São Paulo, 2011.

DAL ROSSO, Sadi. Mais trabalho! A intensificação do labor na sociedade contemporânea. São Paulo: Boitempo, 2008.

DEBORD, Guy. A sociedade do espetáculo. Rio de Janeiro: Contraponto, 1997.

DURKHEIM, Émile. Da divisão do trabalho social. São Paulo: Martins Fontes, 1999 (Coleção Tópicos).

FERREIRA, Aurélio Buarque de Holanda. Novo Aurélio século XXI: o dicionário da língua portuguesa. Rio de Janeiro: Nova Fronteira, 1999.

FREIRE, Paulo. Pedagogia da autonomia: saberes necessários à prática educativa. São Paulo: Paz \& Terra, 1996 (Coleção Leitura).

FREIRE, Paulo. Pedagogia do oprimido. Rio de Janeiro: Paz e Terra, 2011.
HOLLANDA, Chico Buarque de. Geni e o Zepelim. In: História da música popular brasileira: grandes compositores. São Paulo: Polygram, 1982.

MARX, Karl. Contribuição à crítica da economia política. São Paulo: Martins Fontes, 1983.

MARX, Karl. 0 capital: crítica da economia política. Rio de Janeiro: Nova Cultural, 1996 (Livro 1, v. 1).

SARAMAGO, José. Ensaio sobre a cegueira. São Paulo: Companhia das Letras, 2008.

SÊNECA, Lúcio Aneu. Consolação a minha mãe Hélvia / Da tranqüilidade da alma / Medéia. In: AURÉLIO, Marco et al. Antologia de textos. São Paulo: Abril Cultural, 1985. (Coleção Os Pensadores).

SILVA, Ana Filipa Isidoro. 0 mito de Hércules recriado: da loucura trágica de Eurípides à serenidade estóica de Séneca. 2008. Dissertação (Mestrado) - Lisboa, Portugal: Faculdade de Letras da Universidade de Lisboa, 2008.

\section{SOUZA, Evelise Guioto de. Dogville, filme e} crítica. 2007. Dissertação (Mestrado) - São Paulo: Faculdade de Filosofia, Letras e Ciências Humanas da Universidade de São Paulo, 2007.

TEIXEIRA, Inês Assunção de Castro. Da condição docente: primeiras aproximações teóricas. Educ. Soc., v.28, n.99, Campinas, maio-ago. 2007. p.426-443.

TIREL, Astrid. Dogville: um conto urbano. Sociedade e Estado, v.19, n.1, Brasília, jan-jun. 2004. p.215-224.

TRIER, Lars von. Dogville. São Paulo: Califórnia Filmes, 2003.

TRIER, Lars vo. Manderlay. São Paulo: Califórnia Filmes, 2006. 
